\title{
The Plight of Old English in New India
}

\author{
Milton Sarkar ${ }^{1}$ \\ ${ }^{1}$ Faculty of English Language \& Literature, APC College, Kolkata, West Bengal, India \\ Correspondence: Milton Sarkar, Faculty of English Language \& Literature, APC College, Kolkata, West Bengal, \\ India. E-mail: drmiltonsarkar@gmail.com
}

Received: May 17, 2017 Accepted: June 18, 2017 Online Published: July 26, 2017

doi:10.5539/ijel.v7n5p46 URL: http://doi.org/10.5539/ijel.v7n5p46

\begin{abstract}
Globalization and the new media boom over the last couple of years have created a divide between the old and the new India. One of the most significant phenomena of this so-called new India is the emergence of English as a lingua franca but not in the proper form of it. In this digital age of online communication [email, text messaging (SMS), instant messaging (WhatsApp, Hike, AOL etc.)], Blogging, Microblogging (Twitter, Tumblr, FriendFeed etc.) and so forth writing (with word limit of, say 160/140) is bound to be smaller than it used to be earlier, but that must never mean that one is free to flout the rules of grammar wholesale. English used in the various sections of new media, especially in the Social Networking Sites [SNS(s)] is in a desperate plight. This article is a probe into the predicament of old English in new India.
\end{abstract}

Keywords: India, New Media, English language, plight

\section{Introduction}

\section{1}

Language is dynamic. As life stops without dynamism, so does a language. In these days we hardly want "Queen's English" to dangle like a dead albatross around each English-speaking Indian's neck. The clever "mixing" and "switching" of codes (languages) seldom fail to achieve the desired goal. When Coke says thanda matlab Coca cola (cold means Coca Cola) and Pepsi asserts yeh hi hai right choice baby (this is the right choice baby) - the target is certainly achieved. We rarely stamp Akshay Kumar as a linguistic misfit when he utters: fit hai boss [it (the undergarment he endorses) fits well.]

\section{2}

Globalization and the emergence of New Media have created a divide between the old and the new India. New Media, as we know, is the 21 st century means of mass communication using digital technologies like the internet. It includes websites such as online newspapers, blogs, wikis, video games and above all, social media like Facebook, WhatsApp, Twitter and so forth. New Media evolves continuously; in fact, the definition changes daily and will continue to do so. Over the last couple of years New Media has really gone from strength to strength. The debate has always been there whether we should write as we speak or speak as we write. But the so-called Social Media boom has given birth to Big Bang of a different sort. The formation of English as a lingua franca around the Social Networking Site(s) is actually, to a great extent, deforming the language itself! English used in the various sections of New Media, especially in the Social Networking Sites [SNS(s)] is in a desperate plight. This article is a probe into the predicament of old English in new India. One may wonder whether "Old" English does fall short in the making of "New" India. But a deeper probe into the matter reveals that the problem lies not with the language concerned but with the truant user of it.

\section{Literature Review, Method, Results and Discussion}

\section{1}

It has been taken for granted that English is everybody's cup of tea as far as Social Media is concerned. The old saying might get rewritten:

Everything is fair

In Facebook n Twitter...

The "post(s)" on the "wall(s)" are really astounding. After an exciting Europe tour Sohini’s post: 
...went on a cruise to the area where the Titanic sank to honour the passengers.

The dangerous arrangement of the words implies that the famous ship (The Titanic) sank on its maiden voyage only to honour its passengers!

Salini's rejoinder:

...sitting cosily inside PVR, watching Rustom, the iphone7 started ringing.

One may well think that nowadays it is possible to watch movies on cell phones, but oh my God, This Apple phone can watch movies on its own and that also sitting cosily on a couch, travelling all the way, to the PVR! A proper arrangement of the words could have saved Sohini along with her readers: “... to honour the passengers, went on a cruise to the area where the Titanic sank." Salini's soul could have been saved had she written: "...I am sitting cosily inside PVR, watching Rustom, and my iphone7 started ringing." The readers should have been informed that the verbals (participles) sitting and watching refer to Salini and not to her iphone7. After Sohini and Salini, Vijender joins the group:

I have seen Rustom yesterday.

Somebody should have told Vijender that with adverb denoting time past, he should have used just the simple past and never the present perfect:

I saw Rustom yesterday.

Manish, the fourth of the group posts:

I saw three different movies yesterday.

One may well wonder whether the exclusion of different could ever mean three same movies to anybody! The different is just redundant here.

Nanda's post:

I saw Rustom yesterday ...but I didn't like the movie.

Nita typed:

I also didn't like the movie.

If Nita knew that this also is meaningless here, she would have (and should have) written:

I didn't like the movie either.

Or,

Neither/Nor did I.

2.2

When the proud mother's post proclaims that she is "having three sons," the receiver (especially the native speaker) may get the message that she is actually uploading from inside the labour room! The lady could just have declared that she had three sons.

2.3

After buying a camera from $O L X$ Arvind's post:

the price is very less.

Poor fellow has not been told that very cannot go with the comparative (less being the comparative of little).

Thus Dipa was right when she wrote (after buying a camera from the same $O L X$ ):

the price is very low.

But then Samir's enthusiastic post:

The Flipkart price is equally as low.

Samir should have been told that as is absolutely redundant after equally:

The Flipkart price is equally low.

Navin's comment:

...both OLX and Flipkart are low price sites.

Navin should have known that both must go with the word(s) showing point(s) of commonality: 
...OLX and Flipkart are both low price sites.

2.4

Hritik's post:

...want a tripod for my wife with teak wood legs.

Let's visualize Hritik's wife with teak wood legs! A proper arrangement of words could easily have saved the lady's legs:

...want a tripod with teak wood legs for my wife.

Reading this, Harmeet (from another group) made several cheap jibes at Hritik. After providing Harmeet with some "fitting" reply, this group's post:

Harmeet-jibes had been responded to by Dipa.

But they should have known that English does not work properly in the passive and it would have been better for them to write:

...Dipa responded to Harmeet-jibes.

At the end of this virtual scuffle, Hritik's post:

...will have one cup of coffee.

But problem crops up again, for he does never mean one cup (as opposed to two/three cups) but some coffee to drink. The notion of number is vague in this context and he should just have said:

...will have $a$ cup of coffee.

2.5

The other week a government official of a state was found saying (on a YouTube video):

...big big industrialists have come to this business summit...they will set up big big and small small industries here...even small small villages will be benefited.

Nobody probably dared to tell him that just one big/small would have done. This kind of a translation (from L1) is ridiculous since English does not permit such "reduplication" (Sanyal 315).

2.6

There was a hullabaloo in the KPCC WhatsApp group when it was written that:

...only Rajib changed the marks in the report about the students' progress.

Rajib downright denied the sole responsibility of changing the marks and said that it was the decision of the department. Lopadi eased the linguistic confusion by pointing out to the fact that the mere positioning of only can give entirely different meanings:

...Rajib only changed the marks in the report about the students' progress.

...Rajib changed only the marks in the report about the students' progress.

...Rajib changed the marks only in the report about the students' progress.

...Rajib changed the marks in the report about the students' only progress.

2.7

The active-passive confusion (mentioned earlier in Harmeet's case) creates problem here as well when a young learner comments:

...while collecting data for my application, the position was filled.

So Subhodayda had to say that it should be written as:

... while collecting data for my application, I found that the position had been filled.

Or,

... while I was collecting data for my application, the company filled the position.

Otherwise it would mean that the position was collecting the data.

2.8

In the college WhatsApp group Sanjana wrote: 
...Principal has authority to attest the signature however he is out of the country for two weeks.

Subhroda said that Sanjana should add a semicolon or a period before however:

...Principal has authority to attest the signature; however he is out of the country for two weeks.

Or,

...Principal has authority to attest the signature. However he is out of the country for two weeks.

2.9

On a Rajasthan trip Sivangi wrote on her Facebook wall:

...the sanctity should be maintained. Although there is no clear Temple authority for doing so.

Somebody should have told her that this kind of fragments should be rectified either by adding a verb or by attaching a dependent clause or phrase to an independent clause:

...the sanctity should be maintained, although there is no clear Temple authority for doing so.

2.10

Manav wrote that he "planned on gliding, fishing and sleep."

Samir wrote:

I like to swim, playing cricket, and riding.

Prithadi said that Manav should have written that he "planned on gliding, fishing and sleeping."

And Samir should have written:

I like to swim, play cricket, and ride.

Parallelism refers to similar structure of words, phrases or clauses within a sentence. In her book E-Writing Diana Booher comments that unparallel structures "grate on the ear, make skimming difficult...obscure the meaning and slow the reader's pace" (182). To cite one of her examples:

Unparallel: One of the benefits of the call-forwarding system is that the initiator has complete control of when it can be done, to whom it can be forwarded, and for any length of time.

Parallel: One of the benefits of the call-forwarding system is that the initiator has complete control of when, to whom and for what time the forwarding can be done. (180-81)

2.11

An online directive says:

Each Principal should inform his pupils of the new regulations. They should also hold awareness programmes for all concerned.

(Who should hold the awareness programmes? They in the second sentence may refer to pupils, but the word also implies that the sender is still talking to each Principal). Pronouns must agree with their antecedents. A revision is required to make the meaning clear:

Principals should inform their pupils of the new regulations. The Principals should also hold awareness programmes for all concerned.

Thomas Elliott Berry warns us of the error of the "remote antecedent" resulting from placing so many words between a noun/pronoun and its antecedent that we either have to "strain to find the antecedent" or the "whole idea becomes vague":

Vague: The horses galloped after the baying hounds, up hill and down dale, in pursuit of the fox. Never did they seem to tire.

Better: The horses galloped after the baying hounds, up hill and down dale, in pursuit of the fox. Never did the horses seem to tire. (120-21)

2.12

On the eve of the Pattaya tour Prasant's enthusiastic post:

Karma, Sukhu and me are going to Pattaya.

Sanchitadi had to tell him that it should be written as:

Karma, Sukhu and I are going to Pattaya. 
The "case" of the pronoun has to be appropriate to how the pronoun works in the sentence/clause. That is, only nominative (subject) pronouns (I, you, she, he, it, we, they, who, whoever) can act as subjects of a sentence/clause and objective pronouns (me, you, her, him, it, us, them, whom, whomever) can act as objects. That is why Sanchitadi made him replace $m e$ with $I$.

Diya complains bitterly that:

...neither the tour-guide nor his two associates has accompanied us to the Pattaya beach.

Pratick advised Diya that she should write:

...neither the tour-guide nor his two associates have accompanied us to the Pattaya beach.

Verbs should agree with their subjects (a singular subject needs a singular verb and a plural subject needs a plural verb).We should treat conjunctions either-or/neither-nor as separate units and make the verb agree with the nearest subject. If one of the units is plural (as in the present case) we are to place the plural unit last and make the verb plural accordingly.

Then came Vimal's twit:

I also adviced Diya (after Pratick Sir) to be careful about the use of verbs.

This time Sarbanidi had to say that Vimal should have written:

I also advised Diya (after Pratick Sir) to be careful about the use of verbs.

The distinction between noun advice and verb advise has to be maintained.

2.13

Just before the NAAC visit to the college Devika's post:

a trio of first-year girls are scheduled to dance...

Arpitadi said that it should have been: "a trio of first-year girls is scheduled to dance..." as the true subject is "trio" and not the "girls."

One of the members of the NAAC peer team entered the English Honours classroom and wrote on the blackboard:

"The DPI said the Principal is a fool."

All the activities came to a halt...

The NAAC member asked the class to punctuate the sentence...

Pradipta came to their rescue and wrote:

"The DPI," said the Principal "is a fool."

Sometimes proper punctuation can save our reputation, may be, life as well.

Jayita from the same class wrote on her Facebook page:

I am from Brojosundari Girl's school.

Damini provided the correction:

I am from Brojosundari Girls' school.

2.14

At times right could be wrong for someone if the so-called "wise" majority is to be granted. After demonetisation poor Mitul wrote on her Facebook wall:

...a Reserve Bank of India directive regarding the exchange of the old notes reads...an RBI official has told the NDTV...

Her post caused a furore among the netizens... “ $a$ Reserve Bank of India”... “an RBI”! Situation became normal only when Subhra madam made it clear that RBI would take an since pronouncing the first initial (i.e. R) we begin with a vowel sound despite the fact that $\mathrm{R}$ is a consonant letter and majority must not always be granted.

2.15

When the meat was ruined, Tina wrote on her wall:

...the meat which was in the meat safe was ruined. 
Commenting on the same event, Mina (Tina's sister) wrote:

...the meat, which was in the meat safe, was ruined.

They hardly knew that the same event produced two meanings! Tina's post implies that only some of the meat was ruined. Most probably some was kept elsewhere (may be in the refrigerator) and escaped harm. Mina's post implies that all the meat was in the meat safe and ruined. Thomson and Martinet point out the importance of commas in relative clauses. In case of Tina's comment we have a "defining relative clause, which defines or limits" the noun meat. In Mina's case we have a "non-defining clause, which does not define or limit the noun it follows" (89).

2.16

One Facebook post became viral of late:

Delhi is more polluted than any city in India.

F T. Wood in his Current English Usage draws our attention to this "very frequent mistake" (23). Any city in India includes Delhi. It should have been:

Delhi is more polluted than any other city in India.

2.17

After a check-up Radhika's sad post:

Doctor's advice....will have to wear spectacle.

She never knew that she made a spectacle of herself with her wish to "wear spectacle" as it should have been:

Doctor's advice...will have to wear spectacles.

There is a gulf between the singular spectacle ["a performance or an event that is very impressive and exciting to look at" (Hornby 1470)] and the plural spectacles ["glasses" (Hornby 1470)].

2.18

Anuj asked (in WhatsApp):

Is not Tania here?

Which should have been:

Isn' $t$ Tania here?

Jon Hird discusses the matter in his book Verbs and Tenses (13). We make a negative question by adding $-n^{\prime} t$ to the auxiliary verb and not by using the full form not. However, we can place not after the subject:

Is Tania not here?

2.19

Could not but reproduce two Facebook posts verbatim:

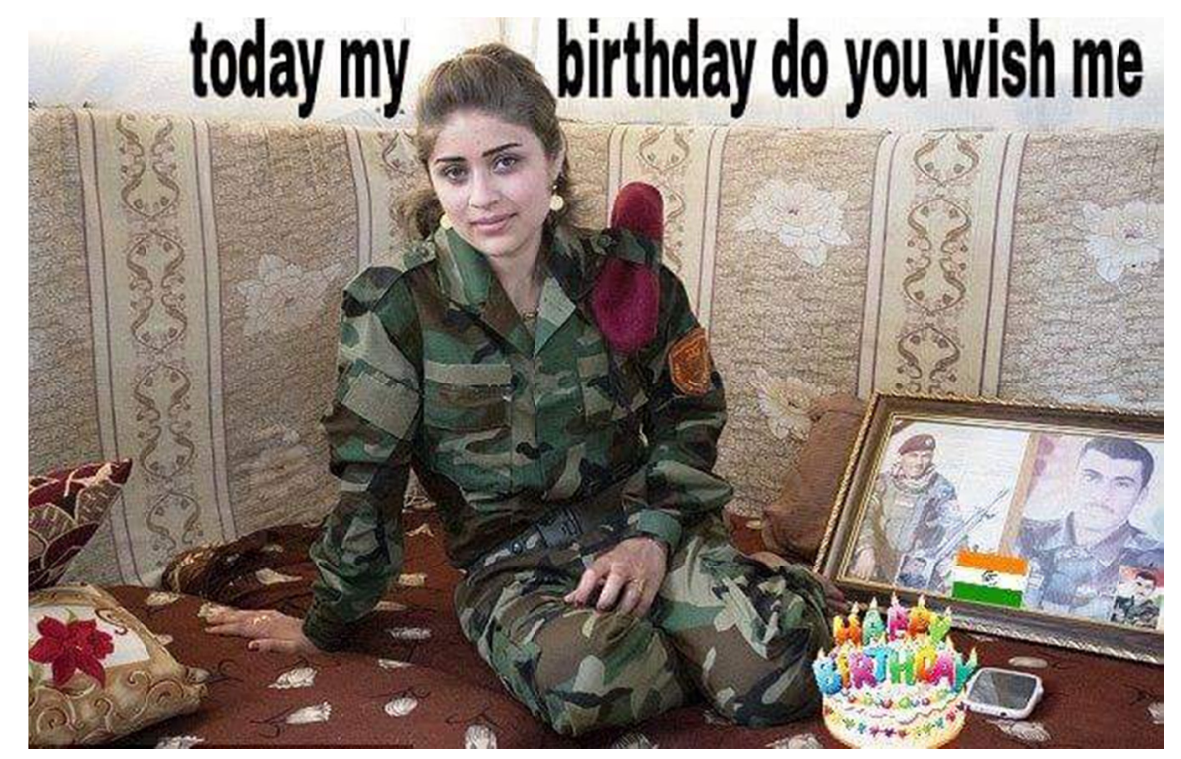




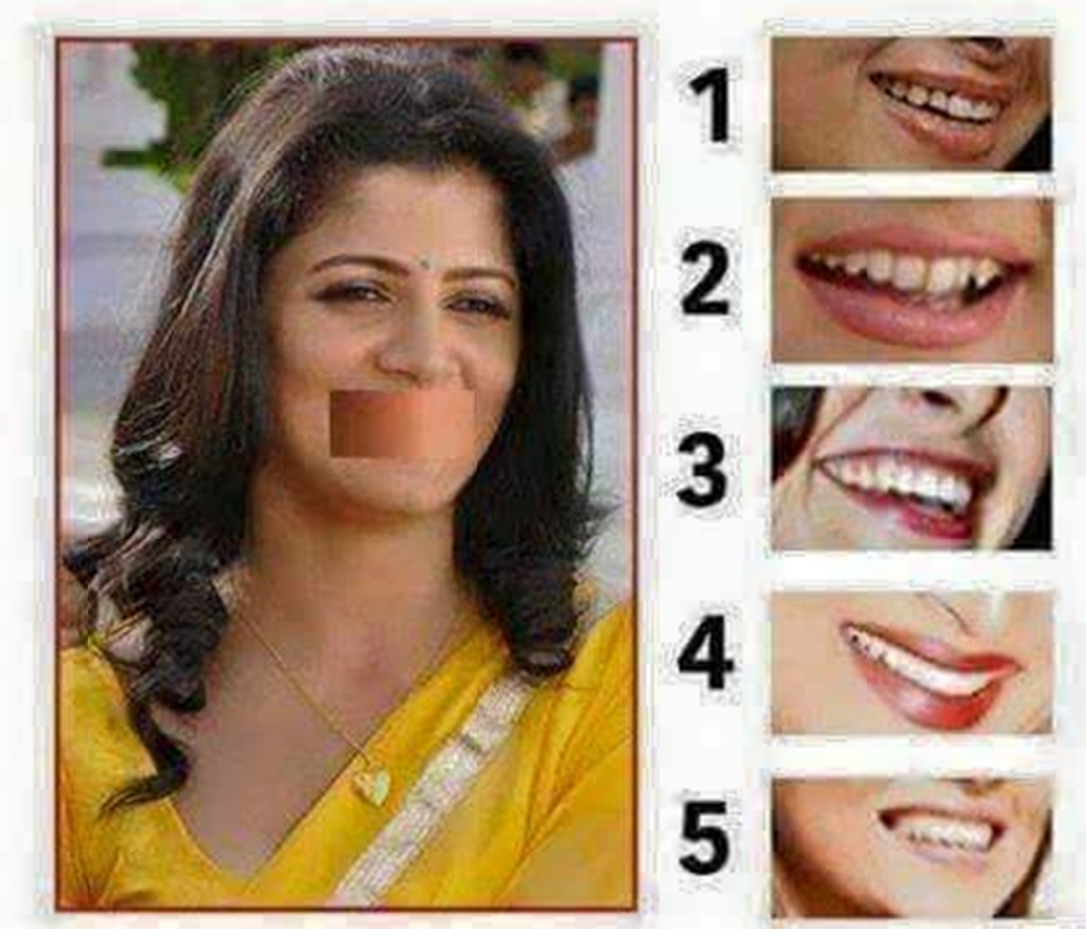

which my lips.... adadadad

"today my birthday do you wish me"... "which my lips"...- no comment is enough.

2.20

Last Wednesday I had to bear the brunt of a Skype conversation. The Call Centre boy was talking to an IT girl:

You go there...

Yeah, Yeah, Yeah...I go...Rahul go...Tina go...everybody go...

You come...

No I wented Monday...

You doesn't know...I miss you

You miss me...then tomorrow you come...or I come

Who come...you or me

God knows who came but what came to my mind was the Skype catchline:

Skype keeps the world talking, for free...

\section{Conclusion}

India has started living the digital life (one can well remember the Jio jingle: Jio digital life). In this age of online communication [email, text messaging (SMS), instant messaging (WhatsApp, Hike, AOL, Skype etc.)], Blogging, Microblogging (Twitter, Tumblr, FriendFeed etc.) and so forth writing (with word limit of, say $160 / 140$ ) is bound to be smaller than it used to be earlier, but that must never mean that one is free to write almost anything. This article begins with the dynamism of language, but the acknowledgement of dynamism is by no means meant to discount the rules of grammar. A wrong in black and white remains wrong in digital platform as well - hence this caveat.

\section{References}

Berry, T. E. (1976). The Most Common Mistakes in English Usage. New Delhi, India: Tata McGraw-Hill. Booher, D. (2001). E-Writing: $21^{\text {st }}$-Century Tools for Effective Communication. Grapevine, TX: Macmillan. Coca Cola. (2014). Thanda matlab Coca cola [Television commercial]. Kolkata, WB: Star Sports. 
Dollar. (2017). Fit hai boss [Television commercial]. Kolkata, WB: ZEE TV.

Hird, J. (2013). Oxford Learner's Pocket Verbs and Tenses. Oxford, England: Oxford University Press.

Hornby, A. S. (2005). Oxford Advanced Learner's Dictionary of Current English (7th ed.). Oxford, England: Oxford University Press.

Pepsi. (2014). Yeh hi hai right choice baby [Television commercial]. Kolkata, WB: Star Sports.

Reliance Jio. (2016). Jio digital life [Television commercial]. Kolkata, WB: ZEE NEWS.

Sanyal, J. (2006). Indlish. New Delhi, India: Viva.

Skype keeps the world talking, for free. (2017, May 13). Retrieved from https://www.skype.com/en/

Thomson, A.J., \& Martinet A.V. (1986).A Practical English Grammar (4th ed.). New Delhi, India: Oxford University Press.

Today My Birthday Do You Wish Me. (2017, February 20). [Photograph]. Retrieved from https://www.facebook.com/?stype=lo\&jlou=AfeGr-BeoQafgIpkfu2fOoscFbS6H80yq96hf3qtfcHzFL3j-VTu F9Tx51jsBltCrnkdzQkZaN5QbQ-P7ndsdgY117sW19DAp5SE0cwlzpRh0w\&smuh=3317\&lh=Ac-nmiYfU Nku9PLr

Which My Lips. (2017, March 11). [Photograph]. Retrieved from https://www.facebook.com/laughingcolours/photos/a.10150471189319578.388832.173770089577/101 $53421997854578 /$ ?type $=3 \&$ theater

Wood, F. T. (1984). Current English Usage (2nd ed.). London, England: English Language Book Society.

\section{Copyrights}

Copyright for this article is retained by the author(s), with first publication rights granted to the journal.

This is an open-access article distributed under the terms and conditions of the Creative Commons Attribution license (http://creativecommons.org/licenses/by/4.0/). 